\title{
HUBUNGAN STATUS GIZI DENGAN TINGKAT PERKEMBANGAN BALITA WILAYAH KERJA PUSKESMAS PELANGAN KABUPATEN LOMBOK BARAT
}

\author{
Novi Enis Rosuliana ${ }^{1}$, Ageng Abdi Putra ${ }^{2}$ Hernawati $^{3}$ \\ ${ }^{1,2,3)}$ Sekolah Tinggi Ilmu Kesehatan (STIKES) Mataram \\ Email:ikhsanovi@gmail.com
}

\begin{abstract}
ABSTRAK
Pertumbuhan dan perkembangan pada balita merupakan suatu periode yang menentukan kualitas balita kedepannya. Kondisi pertumbuhan yang kurang akan berdampak pada tingkat perkembangan balita. Terdapat dua faktor utama yang mempengaruhi pertumbuhan dan perkembangan balita, meliputi faktor genetik dan faktor lingkungan. Salah satu faktor biologis yang berkaitan dengan tumbuh kembang adalah gizi. Tujuan penelitian ini adalah mengetahui hubungan status gizi dengan perkembangan balita di Dusun Lendang Guar Desa Kedaro Kecamatan Sekotong. Desain penelitian yang digunakan adalah survey cross sectional. Sampel sebanyak 63 orang dengan teknik purposive sampling. Penelitian ini menggunakan uji analisa rank spearman. Hasil penelitian menunjukkan nilai $\alpha<0,05$ sebesar 0,000 yang artinya Ho ditolak dan Ha diterima. Terdapat hubungan yang bermakna antara status gizi dengan tingkat perkembangan balita. Selain itu nilai koefisien korelasi adalah 0,631, yang menunjukkan terdapat hubungan yang kuat. Kesimpulan dalam penelitian ini adalah status gizi balita memiliki hubungan yang kuat dengan tingkat perkembangan. Menunjukkan bahwa pemenuhan kebutuhan fisik atau pertumbuhan sangat menunjang terhadap tingkat perkembangan. Saran dalam penelitian ini yaitu pentingnya meningkatkan kualitas makanan balita untuk meningkatkan kualitas perkembangan.
\end{abstract}

Kata Kunci : Balita; Pertumbuhan; Perkembangan; Status gizi,

\section{RELATIONSHIP OF NUTRITION STATUS WITH TODDLER DEVELOPMENTAL LEVEL}

\begin{abstract}
Growth and development in infants is a period that determines the quality of toddlers going forward. Poor growth conditions will have an impact on the level of development of toddlers. Two main factors affect the growth and development of infants, including genetic factors and environmental factors. One of the biological factors related to growth and development is nutrition. The purpose of this study was to determine the relationship of nutritional status with the development of toddlers in Lendang Guar, Kedaro Village, Sekotong District. The research design used was a cross-sectional survey. A sample of 63 people using a purposive sampling technique. This study uses the Spearman rank analysis test.The results showed a value of $\alpha<0.05$ of 0,000 which means that Ho was rejected and Ha was accepted. There is a significant relationship between nutritional status and the level of development of children under five. Besides, the correlation coefficient value is 0.631, which indicates there is a strong relationship.The conclusion in this study is the nutritional status of children under five has a strong relationship with the level of development. Show that the fulfillment of
\end{abstract}


physical needs or growth is very supportive of the level of development. Suggestions in this research are the importance of improving the quality of toddler food to improve the quality of development.

Keywords: Toddlers; Growth; Development; Nutritional status,

\section{PENDAHULUAN}

Anak merupakan seseorang yang belum berusia 18 (delapan belas) tahun, termasuk anak yang berada dalam kandungan. Anak merupakan harapan, generasi muda penerus cita-cita dan perjuangan bangsa (Undang-undang perlindungan anak, 2012). Balita merupakan masa emas (golden periode), sekaligus disebut masa kritis (critical period) (Soetjiningsih \& Ranuh, 2016). Oleh karena itu peningkatan pertumbuhan dan perkembangan pada anak sangat ditekankan demi menghasilkan anak yang berkualitas.

Pertumbuhan (Growth) merupakan suatu indikator global terbaik yang diakui secara internasional dalam menentukan kesejahteraan fisik pada anak. Pertumbuhan yang buruk pada anak akan berdampak pada mortalitas, morbiditas dan gangguan perkembangan (Thamaria, 2017 ). Penilaian pertumbuhan pada balita adalah dengan menentukan status gizi balita (Kementrian Kesehatan RI, 2010).

Status gizi merupakan salah satu faktor penting dalam mencapai derajat kesehatan yang optimal. Status gizi merupakan suatu gambaran bagi individu sebagai dampak dari asupan gizi seharihari. Apabila terdapat masalah dalam pemenuhan asupan gizi maka akan timbul masalah gizi (Soetjiningsih \& Ranuh, 2016).

Pemantauan Status Gizi (PSG) tahun 2017 menyatakan bahwa persentase gizi buruk pada balita usia 0-59 bulan di Indonesia adalah 3,8\%, sedangkan persentase gizi kurang adalah 14\%. Hal tersebut tidak berbeda jauh dengan hasil PSG tahun 2016 yaitu persentase gizi buruk pada balita usia 0-59 bulan sebesar
3,4\% dan persentase gizi kurang sebesar 14,43\%. Nusa Tenggara Timur adalah provinsi tertinggi gizi buruk dan gizi kurang pada balita usia 0-59 bulan sedangkan Bali adalah provinsi dengan persentase terendah (Kemenkes RI, 2018).

Persentase balita sangat kurus dan kurus usia 0-59 bulan di Indonesia pada tahun 2017 adalah 2,8\% dan 6,7\%. Tersebut mengalami penurunan jika dibandingkan tahun 2016 yaitu persentase sangat kurus dan kurus sebesar 3,11\% dan 7,99\% (Kemenkes RI, 2018). Data gizi buruk dan gizi kurang diwilayah NTB (Nusa Tenggara Barat adalah 4,3\% dan $18,3 \%$ dan menduduki peringkat ke-5 dari seluruh provinsi di Indonesia (Kemenkes RI, 2018).

Berdasarkan data dari Puskesmas Pelangan Sekotong Barat Kabupaten Lombok Barat, pada bulan November 2017 jumlah balita laki-laki sebanyak 49 dan balita perempuan sebanyak 43 balita, dengan pravelensi $\mathrm{BB} / \mathrm{U}$ gizi kurang sebanyak $26,8 \%$ dan gizi baik sebanyak $78,26 \%$ dan sangat kurus $6,52 \%$. TB/U stunting sebanyak $56,52 \%$ normal sebanyak $43,47 \%$ sangat pendek $2,17 \%$ balita, sedangkan BB/TB kurus 8,69\%, sangat kurus 2,17\% normal, 69,56\% balita (Puskesmas Pelangan Sekotong Barat, 2017).

Masalah gizi pada balita merupakan salah satu faktor yang berkatan dengan perkembangan pada balita. Perkembangan merupakan bertambahnya kemampuan (skill) struktur dan fungsi tubuh yang lebih kompleks, dalam pola yang teratur dan bisa diramalkan (Soetjiningsih \& Ranuh, 2016). Berdasarkan hasil penelitian menunjukkan bahwa anak dengan status 
gizi normal memiliki perkembangan motorik lebih baik dibandingkan dengan anak yang status gizi tidak normal (Humaira, Dianne Jurnalis, \& Edison, 2016).

Gangguan perkembangan ditemukan pada $12-16 \%$ populasi anak di Amerika. Penelitian di Indonesia yang dilakukan di Kabupaten Bandung, Jawa Barat menunjukkan bahwa 20-30\% anak balita mengalami gangguan perkembangan, sebagian besar gangguan perkembangan yang terjadi yaitu adanya keterlambatan pada aspek motorik kasar dan bahasa/bicara, kondisi terjadi karena kurangnya stimulasi (Kemenkes RI, 2014). Tujuan dari penelitian ini adalah untuk mengetahui hubungan status gizi dengan perkembangan balita

\section{BAHAN DAN METODE}

Desain penelitian yang digunakan dalam penelitian ini adalah survey crossectional. Populasi adalah ibu dan balita yang mempunyai usia 1-5 tahun berjumlam 94 balita yang berada di Dusun Lendang Guar Desa Kedaro Kecamatan Sekotong Lombok Barat.

Penelitian dilakukan pada Bulan Mei 2018 di Dusun lendang Guar Desa Kedaro Kecamatan Sekotong Lombok Barat. Jumlah sampel dalam penelitian ini sebanyak 63 orang dengan menggunakan teknik Purposive sampling. Kriteria inklusi dalam penelitian ini adalah Balita yang berada di Dusun Lendang Guar, berusia 1-5 tahun, bersedia menjadi responden. Sedangkan kriteria eksklusi yaitu balita yang ke luar daerah, dan Balita yang sakit.

Variabel dalam penelitian ini terdiri atas Variabel independen yaitu satus gizi dan dependen adalah perkembangan balita. Sedangkan instrument yang digunakan berupa Kuesiner Pra skrining Perkembangan (KPSP) untuk mengukur perkembangan balita, sedangkan untuk menilai status gizi menggunakan timbangan berat bdang dan mikrotois untuk menentukan BB dan TB balita. Uji analisis menggunakan analisis univariat untuk mengahasilkan distribusi frekuensi, dan analisis bivariate menggnakan uji analisa spearman rank untuk menguji variable status gii dan perkembangan balita.

\section{HASIL DAN BAHASAN \\ HASIL}

Tabel.1 Distribusi Responden

Berdasarkan Pendidikan Orang Tua

\begin{tabular}{|c|c|c|}
\hline Pendidikan & Frekuensi (n) & Persentase (\%) \\
\hline SD & 23 & 36,51 \\
\hline SMP & 19 & 30,16 \\
\hline SMA & 11 & 17,46 \\
\hline S1 & 10 & 15,87 \\
\hline Jumlah & 63 & 100 \\
\hline
\end{tabular}

Tabel. 2 Distribusi Responden ibu berdasarkan Pekerjaan

\begin{tabular}{|c|c|c|}
\hline Pekerjaan & Frekuensi (n) & Persentase (\%) \\
\hline Petani & 35 & 55,56 \\
\hline Buruh & 19 & 30,16 \\
\hline Guru & 9 & 14,28 \\
\hline Jumlah & 63 & 100 \\
\hline
\end{tabular}

Tabel. 3 Distribusi Responden Berdasarkan Usia Ibu

\begin{tabular}{|c|c|c|}
\hline Uisa & Frekuensi (n) & Persentase (\%) \\
\hline$<20$ tahun & 21 & 33 \\
\hline $20-35$ tahun & 32 & 51 \\
\hline$>35$ tahun & 10 & 16 \\
\hline Jumlah & 63 & 100 \\
\hline
\end{tabular}

\begin{tabular}{|c|c|c|}
\hline \multirow{2}{*}{\multicolumn{2}{|c|}{$\begin{array}{lc}\text { Tabel.4 } & \text { Distribusi } \\
\text { Berdasarkan } & \text { Usia Balita }\end{array}$}} & \multirow[t]{2}{*}{ Responden } \\
\hline & & \\
\hline \begin{tabular}{|l|} 
Usia \\
\end{tabular} & $\begin{array}{l}\text { Frekuensi } \\
\text { (n) }\end{array}$ & Persentase (\%) \\
\hline $12-36$ bulan & 31 & 49 \\
\hline $37-60$ bulan & 32 & 51 \\
\hline Jumlah & 63 & 100 \\
\hline
\end{tabular}

\section{Tabel.5 Distribusi Responden} Berdasarkan Jenis Kelamin Responden Balita

\begin{tabular}{|c|c|c|}
\hline Usia & Frekuensi (n) & Persentase (\%) \\
\hline Laki-laki & 34 & 54 \\
\hline Perempuan & 29 & 46 \\
\hline Jumlah & 63 & 100 \\
\hline
\end{tabular}


Tabel.6 Distribusi Responden Berdasarkan Status Gizi Balita (Skor Z indeks BB/TB)

\begin{tabular}{|c|c|c|}
\hline $\begin{array}{c}\text { Status Gizi } \\
\text { Balia }\end{array}$ & $\begin{array}{c}\text { Frekuensi } \\
(\mathbf{n})\end{array}$ & $\begin{array}{c}\text { Persentase } \\
(\mathbf{\%})\end{array}$ \\
\hline Gizi Gemuk & 6 & 10 \\
\hline Gizi Normal & 26 & 41 \\
\hline Kurus & 16 & 25 \\
\hline Sangat Kurus & 15 & 24 \\
\hline Jumlah & 63 & 100 \\
\hline
\end{tabular}

Tabel. 7 Distribusi $\quad$ Responden Berdasarkan Perkembangan Balita

\begin{tabular}{|c|c|c|}
\hline Perkembangan & $\begin{array}{c}\text { Frekuensi } \\
(\mathbf{n})\end{array}$ & $\begin{array}{c}\text { Persentase } \\
(\mathbf{\%})\end{array}$ \\
\hline Sesuai & 24 & 38 \\
\hline Meragukan & 24 & 38 \\
\hline $\begin{array}{c}\text { Kemungkinan ada } \\
\text { Penyimpangan }\end{array}$ & 15 & 24 \\
\hline Jumlah & 63 & 100 \\
\hline
\end{tabular}

Tabel.8 Tabel silang status Gizi dengan Perkembangan Balita

\begin{tabular}{|c|c|c|c|c|c|c|c|c|}
\hline \multirow{3}{*}{$\begin{array}{c}\text { Status } \\
\text { Gizi }\end{array}$} & \multicolumn{6}{|c|}{ Perkembangan Balita } & \multirow{2}{*}{\multicolumn{2}{|c|}{ Total }} \\
\hline & \multicolumn{2}{|c|}{ Sesuai } & \multicolumn{2}{|c|}{ Meragukan } & \multicolumn{2}{|c|}{$\begin{array}{c}\text { Penyimpa } \\
\text { ngan }\end{array}$} & & \\
\hline & $\mathrm{n}$ & $\%$ & $\mathrm{n}$ & $\%$ & $\mathrm{n}$ & $\%$ & $\mathrm{n}$ & $\%$ \\
\hline Gemuk & 6 & 9,5 & 0 & 0 & 0 & 0 & 6 & 9,5 \\
\hline Normal & 16 & 25,4 & 8 & 12,7 & 2 & 3,2 & 26 & 41,3 \\
\hline Kurus & 0 & 0 & 16 & 25,4 & 0 & 0 & 16 & 25,4 \\
\hline $\begin{array}{l}\text { Sangat } \\
\text { Kurus }\end{array}$ & 2 & 3,2 & 0 & 0 & 13 & 20,6 & 15 & 23,8 \\
\hline Jumlah & 24 & 38,1 & 24 & 38,10 & 15 & 23,80 & 63 & 100 \\
\hline
\end{tabular}

\section{BAHASAN}

\section{Status Gizi}

Status gizi pada responden balita dalam penelitian ini menunjukkan bahwa mayoritas responden balita berada pada status gizi normal sebanyak $41 \%$. Namun masih terdapat responden balita dalam kategori gizi kurus dan sangat kurus sebanyak 49\%. Status gizi kurang dan sangat kurus merupakan suatu permasalahan yang terjadi di masyarakat.

Kondisi status gizi ditentukan oleh pemberian asupan makanan pada balita mulai dari mencari, memperoleh dan menerima berbagai informasi mengenai pengetahuan asupan makanan, pemilihan jenis dan variasi makanan. Sikap dan pola pikir ibu dalam menentukan asupan makanan balita adalah didasarkan pada pengetahuan dan informasi yang dimiliki oleh ibu (Jannah, 2014).

Pendidikan responden ibu sebagian besar adalah pendidikan Sekolah Dasar yang merupakan pendidikan tingkat paling rendah dimana memberikan bekal dasar kehidupan. Maksudnya adalah pendidikan dasar prinsipnya masih terkait dengan pola pikir yang sifatnya mendasar dalam memenuhi kebutuhan hidup, sedangkan kemampuan lebih lanjut dalam berinovasi, mengembangkan pengetahuan masih kurang (Ihsan, 2010). Pengetahuan ibu ditentukan oleh tingkat pendidikan, karena semakin tinggi pendidikan maka akan semakin tinggi juga pengetahuan ibu (Mubarak, Chayatin, Rozikin, \& Supradi, 2007).

Selain itu semua responden ibu adalah sebagai pekerja, yaitu mayoritas responden ibu adalah bekerja sebagai petani. Pekerjaan sebagai petani pada responden memberikan penghasilan tambahan namun kondisi penghasilan yang diterima tudak menentu, sedangkan kebutuhan keluarga dalam pemberian makanan anak juga tinggi. Sehingga kondisi tersebut akan berdampak pada penentuan pola asupan makanan yang diberikan.

Aktivitas bekerja tentunya akan membutuhkan waktu tertentu, sehingga waktu bersama keluarga terutama anak akan terbagi, dan akan berpengaruh terhadap status gizi. Kondisi ini akan berdampak ibu akan kehilangan waktu untuk memperhatikan asupan dan pola makanan yang diberikan. Selain itu peranan ibu yang bekerja dalam memberikan pola suhan makan pada balita terkadang akan digantikan oleh orang lain seperti nenek atau pengasuh sehingga asupan makan anak akan tetap terpenuhi (Rozali, 2016).

\section{Perkembangan Balita}

Perkembangan Balita berdasarkan penilain menggunakan Kuesioner Pra Skrining Perkembangan, menunjukkan 
bahwa perkembangan responden balita sebanyak $38 \%$ pada perkembangan sesuai, $38 \%$ meragukan dan kemungkinan ada penyimpangan adalah $24 \%$. Kondisi hasil penilaian perkembangan anak yang meragukan dan kemungkinan ada penyimpangan sejumlah $62 \%$ menunjukkan bahwa masih terdapatnya masalah perkembangan pada anak. Munculnya masalah perkembangan pada anak disebabkan oleh berbagai faktor genetik dan faktor lingkungan (Soetjiningsih \& Ranuh, 2016).

Menurut penelitian (Fadlyana et al., 2016) bahwa faktor-faktor yang mempengaruhi perkembangan balita yaitu umur anak, pendidikan ibu, penghasilan keluarga dan tempat tinggal. Hasil penelitian bahwa sebagian besar pendidikan ibu adalah tingkatan sekolah dasar (SD) dimana SD merupakan tingkatan pendidikan yang paling rendah, hal tersebut menunjukkan bahwa pada ibu yang memiliki pendidikan rendah kurang memiliki pengetahuan dan informasi mengenai bagaimana melakukan stimulasi perkembangan balita, sehingga berdampak pada perkembangan balita.

Selain itu usia responden ibu dalam penelitian ini sebagian besar adalah usia remaja. Masa remaja belum mampu menunjukkan kedewasaannya ketika diperlakukan seperti orang dewasa sehingga sering muncul kegelisahan, pertentangan, kebingungan dan konflik dalam diri (Putro, 2017). Hal tersebut menunjukkan bahwa sebagian besar responden dalam penelitian ini melakukan pernikahan dini. Dampak dari pernikahan dini yaitu akan mengakibatkan terjadinya kehamilan dan persalinan dini sehingga kondisi tersebut menyumbang angka kematian yang tinggi dan keadaan tidak normal bagi ibu system reproduksi masih belum matang untuk melakukan perslinan. Komplikasi yang lain seperti, infeksi, perdarahan hebat, anemia, eklampsia, dan meningkatnya kelahiran premature, resiko stunting yang berakibat terjadinya gangguan perkembangan (BPS, 2016).

Perkembangan balita juga dipengaruhi oleh usia anak. Dimana usia responden balita dalam penelitian ini paling banyak adalah usia pra sekolah sebanyak 32 responden dan tidak terpaut jauh dengan responden yang usia toddler sebanyak 31 responden. Menurut Soetjiningsih \& Ranuh (2016) menyatakan bahwa umur yang paling rawan adalah masa balita, terutama pada umur satu tahun pertama. Kondisi tersebut disebabkan karena pada masa tersebut anak rawan terkena infeksi maupun penyakit dan sering terjadi kurang gizi.

\section{Hubungan Status Gizi dengan Perkembangan Balita}

Hasil uji analisis variabel status gizi dengan variable perkembangan balita menggunakan spearman rank menunjukkan nilai $\alpha 0,000$ sehingga nilai $\alpha<0,05$, artinya $\mathrm{Ha}$ diterima dan $\mathrm{Ho}$ ditolak. Hasil analisis tersbut menunjukkan bahwa terdapat hubungan yang signifikan antara status gizi dengan perkembangan balita. Sedangkan untuk nilai koefisien korelasi diperoleh koefisien korelasi antara status gizi dengan perkembangan balita adalah 0,631 yang menunjukkan adanya hubungan yang kuat.

Hasil penelitian yang dilakukan menunjukkan bahwa anak dengan status gizi normal cenderung memiliki perkembangan yang sedang dan baik, sedangkan anak yang kurus dan gemuk cenderung memiliki perkembangan kurang dan sedang (Rohimah, Kustiyah, \& Hernawati, 2015).

Berdasarkan teori juga menunjukkan bahwa makan memiliki peranan yang penting dalam tumbuh kembang. Kebutuhan anak berbeda dengan orang dewasa, hal tersebut dikarenakan makanan selain untuk aktivitas juga digunakan untuk pertumbuhan. Ketahanan makan (Food security) keluarga mempengaruhi 
status gizi anak (Sotjiningsih \& Ranuh, 2016). Penelitian lain juga menunjukkan bahwa bahwa kondisi kehamilan, komplikasi persalinan, pemenuhan nutrisi, perawatan kesehatan, dan kerentanan terhadap penyakit merupakan faktor yang mengakibatkan gangguan perkembangan pada anak balita (Putri, Lazdia, \& Putri, 2018). Faktor lain yang mempengaruhi status gizi adalah status imunisasi. Imunisasi bertujuan untuk memberikan kekebalan terhadap antigen tertentu untuk mencegah penyakit dan kematian bayi dan anak. Sudah lama diketahui bahwa imunisasi ada hubungannya dengan malnutrisi kaitannya dengan penyakit infeksi yang dapat secara langsung mempengaruhi status gizi anak

(Dwiastuti, 2012;Sukardin, Hemchayat, \& Sinsuesatkul, 2015).

Hasil tabulasi silang dalam penelitian ini menunjukkan bahwa balita dengan status gizi kurus menunjukkan nilai perkembangan meragukan sebanyak 16 responden. Sedangkan untuk status gizi sangat kurus menunjukkan nilai perkembangan kemungkinan mengalami penyimpangan sebanyak 13 responden. Hasil tersbut menunjukkan bahwa semakin baik status gizi balita maka akan semakin bagus nilai perkembangannya. Pernytaan tersebut sejalan dengan teori yang menyatakan bahwa pertumbuhan dan perkembangan balita berjalan beriringan dan tak terpisahkan (Santrock, 2011).

\section{SIMPULAN DAN SARAN}

Status gizi pada responden balita mayoritas adalah status gizi normal, namun terdapat status gizi kurus dan sangat kurus sebanyak 49\%. Hasil tersebut menunjukkan bahwa masih terdapat masalah pemenuhan asupan makan pada balita. Sedangkan untuk perkembangan sebagian besar responden balita dalam kategori sesuai namun terdapat responden balita dengan nilai perkembangan meragukan dan kemungkinan ada penyimpangan sebanyak 62\%. Hasil analisa menunjukkan terdapat hubungan yang signifikan dengan kekuatan hubungan yang kuat antara status gizi dengan perkembangan balita.

Bagi orang tua terutama ibu diharapkan untuk lebih meningkatkan keingin tahuan atau mencari informasi terkait pola asupan makanan pada balita, serta cara untuk memberikan stimulasi perkembangan. Selain itu diupayakan untuk mencegah terjadinya pernikahan dini terkait dampak negatif pernikahan dini yang juga mempengaruhi pertumbuhan dan perkembangan anak. 


\section{DAFTAR PUSTAKA}

Badan Pusat Statistik. (2016). Kemajuan yang tertunda: Analisa data perkawinan usia anak di Indonesia: Jakarta: BPS

Dwiastuti, P dan Prayitno, N. 2012. "Faktor-faktor yang Berhubungan dengan Pemberian Imunisasi BCG di Wilayah Puskesmas UPT Cimanggis Kota Depok tahun 2012. Jurnal Ilmiah Kesehatan. 5 (1)

Fadlyana, E., Alisjahbana, A., Nelwan, I., Noor, M., Selly, S., \& Sofiatin, Y. (2016). Pola Keterlambatan Perkembangan Balita di daerah Pedesaan dan Perkotaan Bandung, serta Faktor-faktor yang Mempengaruhinya. Sari Pediatri, 4(4), 168. https://doi.org/10.14238/sp4.4.2003. 168-75

Ham, kementrian hukum dan. (2012). Undang-Undang Perlindungan Anak. Undang Undang, 1.

Humaira, H., Dianne Jurnalis, Y., \& Edison, E. (2016). Hubungan Status Gizi dengan Perkembangan Psikomotorik Balita di Wilayah Kerja Puskesmas Lapai Padang Tahun 2014. Jurnal Kesehatan Andalas, 5(2), 402-408. https://doi.org/10.25077/jka.v5i2.53 0

Jannah, M. (2014). Hubungan tingkat pendidikan ibu dengan status gizi balita di posyandu bangunsari semin gunung kidul tahun 2014. Jurnal Kebidanan Indonesia, 6(1), 42-52. https://doi.org/https://doi.org/10.364 19/jkebin.v6i1.100

Kemenkes RI. (2014). Peraturan Menteri Kesehatan Republik Indonesia Nomor 66 Tahun 2014 Tentang Pemantauan Pertumbuhan, Perkembangan, Dan Gangguan Tumbuh Kembang Anak. Berita Negara Republik Indonesia Tahun 2014 Nomor 1524, 365.
https://doi.org/10.1017/CBO978110 7415324.004

Kemenkes RI. (2018). Hasil Utama Riskesdas 2018.

Kementrian Kesehatan RI. (2010). Keputusan Menteri Kesehatan RI tentang Standar Antropometri Penilaian Status Gizi Anak. Standar Antropometri Penilaian Status Gizi Anak.

Putri, Y. R., Lazdia, W., \& Putri, L. O. E. (2018). Faktor Yang Mempengaruhi Perkembangan Anak Balita Usia 1-2 Tahun Di Kota Bukittinggi. Real in Nursing Journal, 1(2), 84. https://doi.org/10.32883/rnj.v1i2.264 Rohimah, E., Kustiyah, L., \& Hernawati, N. (2015). Pola Konsumsi, Status Kesehatan Dan Hubungannya Dengan Status Gizi Dan Perkembangan Balita, 10(2), 93100.

https://doi.org/10.25182/jgp.2015.10 $.2 . \% \mathrm{p}$

Rozali, N. A. (2016). Peranan Pendidikan, Pekerjaan Ibu Dan Pendapatan Keluarga Terhadap Status Gizi Balita Di Posyandu Rw 24 Dan 08 Wilayah Kerja Puskesmas Nusukan Kota Surakarta. Naskah Publikasi. Universitas Muhammadiyah Surakrta, 1-16.

Sukardin, Hemchayat, M., \& Sinsuesatkul, S. (2015). Maternal Care Practices Associated with Nutritional Status in Children Under Five Years Old in West Nusa tenggara Province, Indonesia. Journal Health Research, 29, 91-96. https://doi.org/10.14456/jhr.2015.54

Putro, K.Z. (2017). Memahami cirri dan tugas perkembangan masa remaja. APLIKASIA: Jurnal Aplikasi Ilmuilmu Agama, 17(1), 25-32.

Santrock, J.W. (2011). Masa perkembangan anak. Jakarta: Salemba Medika. 
Soetjiningsih \& Ranuh, IG., N., G. (2016).

Tumbuh kembang anak. Jakarta:

EGC.

Thamaria, N. (2017). Penilaian Status

Gizi. Jakarta: Kementerian

Kesehatan Reublik Indonesia.

Undang-Undang Perlindungan Anak.

(2012). Undang Undang, 1. 